\title{
Collective Action “Going Digital”: Overcoming Institutional and Micro-Structural Constraints through Technology Use
}

\author{
Carol Soon \\ Institute of Policy Studies, 1C Cluny Road, House 5, Singapore 259599, Email: carol.soon@nus.edu.sq, \\ Phone: +65 65168372
}

\begin{abstract}
Traditionally, macro-level and micro-level approaches have been used in silos to explain and determine the threshold where one crosses from non-participation to participation in social movements. Technological advancements have enriched but also complicated the process of collective action. This qualitative study is based on the premise that a confluence between political economy approaches, micro-structural analysis and Internet studies is needed to dissect the dynamics behind technology use in collective action. Through in-depth interviews with 26 activist bloggers in Singapore, this study sheds light on how Internet technologies are used by activists to overcome issues of collective incentives, structural proximity and structural availability, and negotiate the institutional terrain.
\end{abstract}

Keywords: Political blogs, collective action, collective incentives, structural proximity, structural availability

ontentious politics comprise "episodic, public, collective interaction among makers of claims and their objects when (a) at least one government is a claimant, an object of claims, or a party to the claims and (b) the claims would, if realized, affect the interests of at least one of the claimants" (McAdam, Tarrow \& Tilly, 2001, p. 5). Social movements - alternative, redemptive, reformative or revolutionary - involve groups of people organized into a coherent collective to engender political or social change (Locher, 2002). Macro-level and micro-level approaches have been used to determine conditions that influence successful mobilization, collective action participation and the threshold or tipping point when one crosses from non-participation to participation.

On the macro level, political economy approaches explain how social movement actors maximize opportunities and negotiate constraints present in their environment (Coston, 1998; Della Porta, 1995; Della Porta \& Diani, 2006). While severe repression and tough policing techniques tend to drive movements underground and discourage peaceful mass protest, an extension of civil liberties by the state fosters the development of formal organizations (Della Porta, 1995). Current work in this discipline suggests an inverse relationship between the degrees of state repression and civility of movement modality, between the centralization of governance and collaboration between state and civil society (Coston, 1998). On the micro level, one's participation or nonparticipation in social movements is shaped by one's structural availability, collective and selective incentives (Klandermans, 1984, 1993; Klandermans \& Oegema, 1987; Olson, 1965, 1968), and one's structural proximity (or lack thereof) to other social movement actors (Buechler, 1995, McAdam \& Paulsen, 1993; Snow, Zurcher \& Ekland-Olson, 1980).

Technological advancements have both enriched and complicated the process of collective action. On one hand, the growing proliferation of blogs, personal, organization and party websites have opened up spaces for contention and transformed the repertoire of collective action. This in turn have lowered people's risks and costs of participation in a movement, and encouraged activism. On the other hand, the ease of participation has also engendered what is commonly 
known as "slacktivism" which threatens to displace sustained and committed involvement in collective action (Christensen, 2011). Furthermore, the noise and clutter in cyberspace has increased fragmentation of publics, resulting in Graber's (2001) "communication ghettos". Although cautioning against technological determinism, Diani (2000) and Tilly (2004) acknowledged that media and technology are fast becoming an important part of the social movement repertoire of contemporary social movements. The increasing adoption of media and Internet technologies have created innovative forms of collective action modalities and increased the range of movement repertoire (Van Laer \& Van Aelst, 2010).

Social movement development never occurs in a socio-political vacuum. A common approach used in social movement studies is to adopt separate strands of analyses, examining in silos macro and micro factors that affect social movement participation. In political communication and Internet studies, a prolific body of work addresses the mobilization effects of new technologies and how technologies change the forms of movement organizations, but do not theoretically and empirically address how the use of technology mediates institutional effects on micro-structural dynamics. There is a thus a gap where these two fields of studies overlap. In addition, although there are promising lines of work pertaining to how blogs, social networking sites and micro-blogs are used for mobilization and organization (e.g., Fiore-Silfvast, 2009; Garrido \& Halavais, 2009; Sessions, 2010), most of these studies remain in the Western context and are situated in libertarian regimes. There is thus a paucity of research on technology use in regimes which have a different political system and culture, and where political communication follows a top-down pattern.

To address this gap, this study adopts a political economy approach in examining the institutional conditions embedded in activists' environment, and how technology enables movement actors to overcome constraints in their institutional environment. Singapore is chosen for the case study due to the paradoxical relationship between democratization and technology adoption. The objectives of this paper are two-fold. First, it identifies conditions in Singapore's institutional context which influence movement participation. Second, it explains how Internet technologies enable movement actors to overcome constraints posed by micro-structural factors such as collective incentives, structural availability and structural proximity. The next few sections review key themes in existing literature pertaining to micro-structural factors, technology use in movement mobilization, and an analysis of the institutional context in Singapore. Following which, the methodology and findings will be presented.

\section{Micro-Structural Considerations in Collective Action Analyses}

The earliest perspective of social movements was the traditional collective behavior perspective developed in the 1950s which viewed movements "as anomalies, symptoms of a system malfunction and strain" (Hannigan, 1985, p.437). Spontaneity and the lack of structure typified early social movements. However, the assumptions of collective actions being founded on people's irrationality and the lack of organization were challenged as scholars became more aware of power concentrations that shape movements and their effects (e.g., labour movements).

The critique of the traditional collective behavior perspective spawned the development of the resource mobilization (RM) theory in the 1960s and early 1970s. The RM theory addressed power dynamics which were neglected in the old school of thought. The increasingly coordinated ways in which collective action took shape led to scholars' recognition of a more organized, structured and patterned form of contentious politics. The late 1960s witnessed the rise of movements in different parts of the world-the civil rights and antiwar movements in the U.S., student protests in Germany, Britain and Mexico, and pro-democracy mobilization in Prague-bringing to the fore what appeared to be planned and deliberate movements (Della Porta \& Diani, 2006). The RM tradition emphasizes the role of rationality, incentives and social networks in determining a movement's success (Buechler, 1993).

Individual cognitive processes which underpin movement participation have helped answer the question of why one participates in collective action even in the presence of free-ridership. 
Klandersman (1984) proposed that "participation in a social movement is seen not as the consequence of predisposing psychological traits or states, but as the result of rational decision processes whereby people weigh the costs and benefits of participation" (p.583). Rationality was manifested through a decision-making process where the decision to participate or not to participate was based on calculations and the weighing of costs and incentives (Klandermans \& Oegema, 1987). This school of thought stemmed from Olson's theory of collective action, rooted in rationality, in which one's actions are primarily driven by self-interest $(1965,1968)$. The role of incentives received much scholarly scrutiny from RM scholars who view movement actors as rational individuals. Klandermans $(1984,1993)$ defined collective incentives as the value of goals as well as one's expectation of the movement's success. He further broke the theoretical construct down into three components: one's expectations about the number of participants, one's expectations about his or her own contribution to the probability of success, and one's expectations about the probability of success if many people participate (Klandermans, 1984).

Second, studies have shown that one's structural proximity to other activists plays a critical role in positively influencing one's participation in social movements. Social network perspectives elucidate individuals' involvement in collective action, especially in situations where there was an apparent lack of tangible incentives and benefits (Klandermans \& Oegema, 1987). Relationships formed among social entities (i.e., individuals and organizations) pose as channels for the transfer of material and non-material resources (Wasserman \& Faust, 1994). In the context of collective action studies, formal and informal ties in social networks are conduits for the spread of social movements (McAdam \& Paulsen, 1993; Snow, Zurcher \& Ekland-Olson, 1980; Zhao, 1998). For example, one's structural proximity to movement members enhances the mobilizing potential of a group due to prior solidarities and moral commitment (Jenkins, 1983). McAdam's (1986) study of the Mississippi Freedom Summer project found that participants had the greatest number of organizational affiliations and ties to other participants compared to non-participants and withdrawals.

Defined as ties to other members or volunteers in the same movement organization, formal ties were found to be important sources of information for movement participants and social influences (Gould, 1991; McAdam \& Paulsen, 1993). This is because in an organizational setting, interaction opportunities increase communication and facilitates the sharing of grievances (Dixon \& Roscigno, 2003; Gould, 1991; Zhao, 1998). Formal ties also instill loyalty among members, thereby affecting individuals' receptiveness to be recruited, motivated and participation in movements (McAdam, 1986; Passy \& Giugni, 2000). Informal ties, defined as knowing someone from interpersonal networks such as family members, peers, acquaintances and neighbors, are important for the fostering of solidarity, reducing the sense of risk and increasing self-confidence among movement participants (Gould, 1991; Pfaff, 1996). Thus, structural proximity to movement actors through informal and formal ties encourages and sustains participation in collective action as ties cultivate trust, build solidarity and facilitate information-exchange.

The third micro-structural factor which affects movement participation is one's structural availability. Structural availability explains why some individuals are more likely to join a movement after they have been introduced to the movement than others (Snow, Zurcher \& Ekland-Olson, 1980). One will participate in a social movement if one knows of opportunities to participate. However, one must also be capable of using these opportunities and be willing to do so (Klandersman, 1984). In Snow, Zurcher and Ekland-Olson's analysis of member recruitment for Nichiren Shoshu (a religious movement) in the U.S., they found one's participation or nonparticipation to be contingent on the extent to which they are subject to extra-movement networks that demand time, energy and emotional attachment function. Therefore, some individuals will be more available for movement participation because they possess more "unscheduled or discretionary time and because of minimal countervailing risks or sanctions" (p.793). 


\section{Technology Use in Collective Action}

Political parties and non-governmental organizations are increasingly deploying new media technologies to promote political and social causes, reach out to target constituencies, mobilize online action and organize offline activities because of technologies' effectiveness and costefficiency (Bosch, 2010; Langlois, Elmer, McKelvey \& Devereaux, 2009; Stein, 2007). The earliest academic foray in the study of Internet use for political communication focused addressed how political parties and marginalized organizations used Internet technologies such as email, websites and discussion groups. Other than disseminating information and publicizing a cause, the Internet's non-hierarchical networked structure facilitates movement organization and participation. Kreimer's (2001) reference to Internet technologies as "technologies of protest" best encapsulates the role of new media in mobilizing action among fringe groups or civil society organizations (e.g., neoNazism, disability rights, environmentalists and anti-corporate enthusiasts).

Increasingly popular web 2.0 technologies such as Facebook and Twitter have provided additional platforms for marginalized political players to mobilize target constituents in recent years. The progression of online technologies from "web 1.0" to "web 2.0" involved the shift from personal websites to blogs and blog site aggregation and from publishing information to participation in information creation (Flew, 2005). In addition, departing from web content creation that is funded by up-front investments, Flew posits that content creation via web 2.0 technologies is an ongoing and interactive process. Such a participatory approach towards both consuming and producing web content paves the way for the emergence of Winner's (2003) "citizen-governors". Van Laer and Van Aelst (2010) identified a "repertoire" of potential collective actions, distinguished by the role Internet technologies played (Internet-support versus Internet-based) as well as the "threshold" of participation (low versus high involvement), ranging from online petition, virtual sit-in, to hacktivism and creation of protest website and alternative media. Such a wide repertoire of collective actions facilitated by the Internet provides movement actors with many more options in terms of participation and commitment.

Another area of research which has received much scholarly attention is the networking effects of Internet technologies and the establishment of online communities. The instantaneity, reach, and interactivity of computer-mediated communication make it possible for people who share similar ideology or grievances to converge online with ease and speed, hence leading to quick formation of collectives driven by shared goals (Ayers, 2003; McCaughey \& Ayers, 2003; Vegh, 2003). Computer-mediated communication helps to build a sense of solidarity and collective identity (Diani, 2000). Online networking encourages the formation of weak ties which spread movements among diffused networks. Haythornthwaite (2002), Wellman and Gulia (1999) argued that online networks build weak ties which are critical for the diffusion of information, ideas and influences.

Besides reducing transaction costs and increasing access to civil society, Internet technologies are also shaping the way in which movement organizations network internally (between leaders and members, and among members) and externally (among different movement organizations). Examining a wide spectrum of movement organizations (e.g. WTO protest groups, Meet Up, and Amnesty International), Flanagin, Stohl and Bimber (2006) found that structures of movement groups are becoming increasingly less well-defined and nebulous, findings that are supported by Diani (2000) and Langman (2005). Flanagin et.al. posit that "formal, centralized organizations with identified leaders, prescribed roles, and quantifiable resources that are fundamental to collective action theory are no longer the only, nor even the primary, means of contemporary organizing" (p.47). A coterie of work confirms that the structures of movement groups are becoming increasingly less well-defined and nebulous (Diani, 2000; Langman, 2005). Increasingly, social media such as Facebook and Twitter are providing new venues for like-minded individuals to gather in cyberspace, becoming "new types of technocultural spaces" which provide material, communicational and social means for issue publics to exist (Langlois, Elmer, McKelvey \& Devereaux, 2009, p.429). 
This section has established how and why Internet technologies are fast becoming an indispensable part of the repertoire of contemporary collective action. However, these studies do not sufficiently address how the same technologies enable movement actors to overcome microstructural constraints present in their institutional environment. The next section first provides a macro-analysis of the movement environment in Singapore and traces the gradual transformations in the media landscape which have inadvertently created a new political opportunity structure for movement actors to advance their agenda.

\section{Institutional Constraints and Opportunities in Singapore}

Up until 1959 when Singapore achieved self-rule from its British colonial masters, a high degree of civil autonomy was accorded to individuals and groups to pursue their own political and social agenda by the colonists (Gillis, 2005). However, the landslide victory of the People's Action Party (PAP) in the 1959 Legislative Assembly marked a new era in the governance of Singapore. The conditions in post-colonial Singapore posed many challenges for the new government (Chew \& Chew, 1995; Silcock, 1962) but the delivery of economic affluence by the state soon affirmed the polity's belief that such a mode of governance was effective and cultivated "co-option and political discipline" among the citizenry (Rodan, 1998, p.67).

A significant spill-over effect of PAP's pragmatic governance lies in how it culled dissension that was perceived as a threat to nation-building efforts. The regulation of mainstream media was justified on the grounds of building a national identity and social cohesion among Singapore's richly diverse polity and was implemented through a complex set of laws (Banerjee, 2002; Kuo, 1995). Furthermore, the growth of civil society was in part stymied by the PAP-led government's success in supplanting many of the social and economic functions that were traditionally performed by private individuals and organizations during colonial times (Tan, 2007). Any potential development of a vibrant civil society was further constrained by the Societies Act which granted the state discretionary power to deny permit to groups that are "likely to be used for unlawful purposes or purposes that may be prejudicial to public peace, welfare, and good order or against national interest" (Koh \& Ooi, 2004, p.181).

A turning point came in the 1990s when the Singapore economy underwent a major shift when the government embarked on transforming the economy into one that is driven by innovation rather than manufacturing. Within several years, Singapore was ranked among the top 10 economies in the world for active-mobile broadband subscriptions (International Telecommunication Union, The World in 2011, ICT Facts and Figures). However, a complex set of rules and regulations including the Internet Code of Practice and the Class License Scheme were used to govern discourse on the Internet, with past incidents demonstrating the state's resolve in curbing threats to political and social stability. However, the government's attempt to strike a balance between "illiberal political interventions with market-oriented strategies for economic growth", coupled with the architecture of the Internet soon created loopholes that are exploited by marginalized groups and individuals (George, 2003).

Web 2.0 technologies such as blogs are gaining popularity, as revealed in a 2009 survey by the Infocomm Development Authority of Singapore. 12\% of residents create online content (e.g., keep a blog or upload self-produced videos online) and $74 \%$ communicate via social networks, blogs, instant messaging, emails and peer-to-peer platforms (Infocomm Development Authority of Singapore, Annual Survey on Infocomm Usage - Households and by Individuals, 2010). Singaporeans have also begun to leverage leveraging blogs, social networking sites, forums and online videos to raise awareness and garner support for myriad causes (Tan, 2008). Some of these causes include the "No to Rape" campaign, which lobbied for the criminalization of marital rape, started by three youths who leveraged new media technologies such as blogs, Facebook and Twitter (Chew, 2009). Various developments suggest that the Internet has opened up spaces for marginalized individuals and groups to connect with like-minded others, organize meetings and engage in online discussions. It thus appears that there are indeed more possibilities for the public 
to overcome regulatory constraints and contest hegemonic discourse (George, 2003; Ho, Baber \& Khondker, 2002; Ibrahim, 2009).

\section{Method}

The target population comprised political bloggers in Singapore. In the U.S. context, Gil de Zuniga, Veenstra, Vraga and Shah (2010) defined political blogs as "those that have mostly political content" (p.40). This paper sharpens the operationalization and defines political blogs as those that discuss primarily issues pertaining to Singapore politics and governance (e.g. the Singapore government, ruling party PAP, opposition political parties, censorship issues, and marginalized communities' rights).

Keywords searches ("Singapore bloggers" and "Singapore political blogs") were conducted on Google and Yahoo! in 2010 to identify seed pages. Ineligible units such as personal or social blogs which did not meet the criteria for selection were excluded. Blog samples were also collected through two major blog aggregators on a daily basis to reach sample saturation. The third stage of sample collection involved "snowballing" through navigating hyperlinks from the blogroll of each seed page and identifying new political blogs. A total of 224 political blogs emerged from this process. The bloggers were then contacted via email and or comment pages on their blogs. The sample for this study comprised 26 activist political bloggers (four females and 22 males) who participated in in-depth interviews.

A semi-structured interview was used to elicit bloggers' perceptions and opinions regarding their activism participation (e.g. "What does 'activism' mean to you?", "Can you describe your involvement?"), and how they used Internet technologies for their activism work (e.g. "Why do you use the Internet in your activism work?", "Can you describe some of the ways in which you use the Internet to achieve your objectives?"). A semi-structured interview thus enabled me to obtain qualitative descriptions of the life world of the bloggers as well as their interpretation of their meaning (Kvale, 1996). All 26 transcripts were transcribed verbatim and coded line-by-line. Phrases and words were marked according to themes suggested by the text itself, guided by the constructs for collective incentives, structural proximity and structural availability. Condensation of meaning (ibid) where bodies of interview text were compressed into brief statements, representing various themes raised during interviews, preceded the categorization and clustering of themes. Meta-codes or meta-themes were then allocated to clusters of themes which facilitated the analysis of similarities and variances among bloggers' responses. The meta-themes and sub-themes were used to classify the text by appending them to the margins of the transcripts.

\section{Findings \& Discussion}

The interviews indicated that activist bloggers took part in a wide spectrum of activism work. Defined by Locher (2002) as alternative movements, some of these campaigns aimed to change people's attitudes and opinions regarding specific issues, such as the rights of marginalized sexual communities and migrant workers. Other campaigns and activism initiatives were more reformist in nature (Locher, 2002) as they sought to effect changes at the policy level that would lead to constitutional changes. These reformative movements included political campaigning by opposition political parties such as Workers' Party and Singapore Democratic Party, Repeal 377A as well as Bloggers 13 campaign.

In addition to their different nature, the activism work which Singapore political bloggers were involved in also varied in terms of duration, from prolonged campaigns (e.g. opposition party activism) to temporal causes (e.g. Repeal 377A, Free Burma Campaign and JBJ Commemoration). Refer to Table 1 for the profile of these organizations and campaigns. 
Table 1: Profile of Organizations and Campaigns*

\begin{tabular}{l|l}
\hline \multicolumn{1}{c|}{ Group/Party } & \multicolumn{1}{c}{ Description } \\
\hline $\begin{array}{l}\text { Association of Women for Action and } \\
\text { Research (AWARE) } \\
\text { http://www.aware.org.sg/ }\end{array}$ & $\begin{array}{l}\text { Singapore's leading gender equality advocacy } \\
\text { group that is dedicated to removing gender-based } \\
\text { barriers. Since 1985, AWARE has carried out } \\
\text { research into numerous issues affecting women: } \\
\text { workplace sexual harassment, poverty of older } \\
\text { women and Singapore's compliance with UN anti- } \\
\text { gender discrimination standards. }\end{array}$
\end{tabular}

Free Burma Campaign Singapore An independent network of Singapore-based http://freeburmacampaignsg.wordpress.com/ campaigners dedicated to bring about peace, democracy and human rights in Burma through public education, leadership development initiatives, conferences, and advocacy campaigns at national and international levels.

No to Rape
http://www.notorape.com/

The campaign advocates that sexual violence by any person, against any person, is criminal violence. The premise for the campaign is: regardless of whether the victim and perpetrator are married to each other, non-consensual sexual penetration should be treated as rape. The online petition is coordinated by a team of concerned Singaporeans who came together to promote change on this issue. The group is not a formal organization and its members have no shared agenda beyond addressing sexual violence.

Repeal 377A http://www.repeal377a.com/
A website that was established to help Singaporeans gather information, debate the issue and act (Section 377a of the Penal Code of Singapore provides for a jail sentence for up to two years should a man be found to have committed an act of "gross indecency" with another man). Visitors can subscribe to the site's mailing list.

Singapore Anti-Mandatory Death Penalty http://sgdeathpenalty.blogspot.com/ http://www.facebook.com/groups/5081187633/

\begin{tabular}{l|l}
\hline $\begin{array}{l}\text { Singaporeans for Democracy (SFD) } \\
\text { http://sfd.sg/ }\end{array}$ & $\begin{array}{l}\text { An independent non-governmental organization } \\
\text { that focuses on citizen political activism, in } \\
\text { particular to campaigning and advocating for civil } \\
\text { and political reform that will be ultimately reflected } \\
\text { through changes in legislation. }\end{array}$
\end{tabular}

Singapore Democratic Party http://yoursdp.org/
An opposition, political party, the Singapore Democratic Party was formed in August 1980. The Central Executive Committee (CEC) governs the party. Its members are elected by the Party's cadre members at the Ordinary Party Conference held biennially. 
Singapore Queer-Straight Alliance (SinQSA)
http://sinqsa.wordpress.com/

The Online Citizen (TOC) http://theonlinecitizen.com/
Founded by three individuals, SinQSA aims to bridge the gap between queer and straight people by providing an open and inclusive platform where queer and straight persons can engage in meaningful communication.

Established in 2006, the vision of the community blog is to be the leading online source for sociopolitical news and views in Singapore. TOC was gazetted as a political organization in 2011.

Transient Workers Count Too (TWC2) http://www.twc2.org.sg/site/

Since its inception in March 2003, TWC2 has engaged government officials, migrant workers, employment agencies, partner organizations, and the general public. It has become a contact point for migrant workers who encounter problems with their employers, a source of information for employers and the public, and a center for generating action-oriented research.

Workers' Party

http://www.wp.sg/
An opposition political party established in 1957.

Its then Secretary-General became the first opposition Member of Parliament in 1971. Membership in the party is confined to Singapore citizens only above the age of 18 years who are not members of any other political party in Singapore. Every applicant for membership must be proposed by a member of the party and the Executive Council may in its absolute discretion accept or reject or adjourn consideration of each application by simple majority of those present.

*Information obtained from websites and blogs.

\subsection{Increased Collective Incentives through Blogging}

Activist bloggers ascribed a clear sense of vision and value their blogging practices, taking pride in challenging dominant discourse, advancing human rights and freedom of speech in an authoritarian regime. They used their blogs to cultivate a vibrant public sphere by disseminating information and writing commentaries on issues that were omitted or downplayed in mainstream media. Stan attested to the effectiveness of his blog in "getting the word" out on the LGBT (lesbian, gay, bisexual and transgender) movement. Activist bloggers felt that they were part of a larger collective working towards a common goal.

There was a clear acknowledgement of others' presence and participation in a blogging community towards a common good. Chong made specific references to being part of "the same blogging community" and Andy explained how he and other activist bloggers were bound by a common ideology - to challenge hegemonic discourse and engender political and social change. There was recognition of a group membership and explicit references to the self and other political bloggers as part of the same "community." Instead of operating in silos, blogging heightened the feeling of working with others towards a common agenda in promoting democratic discourse and social justice.

The findings also indicated that activist bloggers used their blogs to encourage members of the public to take charge of their own lives and play an active role in a specific issue. The ease in transmitting information which they may otherwise not be able to publish in traditional media outlets helped to garner support from their target constituencies. Blogging provided these activists with the opportunity and means to contribute to public good, and the positive outcomes which stem from 
their blogging reaffirmed their sense of contribution. George described the change he witnessed and Madcow (a prominent actor in the opposition politics scene) spoke about how he was able to increase awareness of local issues through his blog and, in the process, influenced policy-making on issues pertaining to public transportation.

"I see myself as part of a collective socio-political blogging community that is collectively informing Singaporeans of what's going on. l've seen the level of discourse going up since l've started." (George, male, early 30s, technology consultant and opposition party member)

"My blog also has certain influences on my political opponents' [the ruling party] directions. Recently, I blogged about the inadequacies of public transport, and yesterday they reacted and made some amendments to the policies they have, such as adding 150 trips to the MRT [Mass Rapid Transit] system." (Madcow, male, late 30s, member of opposition political party and selfemployed businessman)

There was tacit acknowledgment among activist bloggers that on their own, they did not have the answers or solutions to what they perceived were political, social and economic conundrums that existed in the Singapore society, and the sharing and testing of ideas with one another in the cyberspace constituted a form of collective intelligence and collective action.

\subsection{Increased Structural Proximity to Other Activists}

The Internet's other key contribution is bringing activist bloggers together. Being able to connect to other like-minded individuals through the Internet was, in many cases, an unintended positive consequence of blogging. Prior to the proliferation of the blogging technology, most activists established connections with one another through Internet forums and discussion boards. For example, Evan spoke about how participating in online forums enabled him to meet up with others with similar interest which led to the founding of the organization as well as taking part in activities organized by an opposition political party, Singapore Democratic Party.

"We met up through Internet forums like the Sammyboy coffee shop. We met face-to-face and then some time later, we decided to get involved in the Singapore Democratic Party's activities because we found that their views and ours were very similar actually." (Evan, male, early 30s, founder of SG Human Rights and member of an opposition party)

Such incidental and unintended bonding was also experienced by Rachel whose first foray into activism was sparked by other activists establishing contact via her blog. The effectiveness of the Internet in cultivating new connections and forming alliances was reiterated by Vienna, one of the founders of Singapore Angle, a group blog. The group blog was created out of interaction among Singaporeans who lived in different countries and got to know one another when they commented on one another's blogs. Subsequently, a face-to-face meeting when they returned home led to the formation of the Singapore Angle.

"My blog used to be hosted on Multiply. What happened was I wrote something and on that night, The Online Citizen (a citizen journalism blog) contacted me to ask me to write for them. In the same week, V5 messaged me on Multiply telling me about an event and said that I may be interested to join." (Rachel, female, late 20s, a preschool teacher and human rights activist) 
Digital platforms such as blogs, discussion forums and social networking sites provided an effective way for activists to seek out others who shared a common political ideology and beliefs. Singapore activist bloggers connected with those whom they perceived shared the same goal of advancing human rights issues and political pluralism in a one-party governing system. Cyberspace became a fertile meeting ground for activists such as Hercules to know people whom they otherwise may not have had a chance to meet offline.

An activist's blog also served as an effective vehicle to inform others about his or her cause, hence encouraging fellow Internet users involved in similar campaigns to come forward and connect with the activist. The unanticipated reach garnered by the blog was surprising even to activists themselves. Zazzi, a LGBT activist, spoke about the unexpected opportunities generated by his blogging, which allowed him to further his goal of advancing issues pertaining to human rights and gay equality. His blog created awareness for his activism work and led to networking opportunities. He was invited him to speak at conferences, deliver talks in schools and give interviews with foreign media such as Radio Australia and Al Jazeera.

\subsection{Overcoming Issues of Structural Availability}

The findings from this study confirm that Internet technologies play an important part in helping activist bloggers overcome the lack of structural availability. Internet technologies are used to organize and distribute work among activists, enabling them to circumvent real world constraints posed by their individual commitments. The ease of connection and relatively low cost increased the ease and speed with which activists could converge, pool their resources and work as a team to realize their activist goals.

In the case of Bloggers 13, activist bloggers were adept at deploying various technologies as organization tools to facilitate their teamwork in Bloggers 13. Bloggers 13's proposal for less Internet regulation was put together via email and Google Docs after an initial meeting. George described how the Internet made it possible for members with different professional and academic commitments to collaborate. Given their different backgrounds and commitments (e.g. university lecturer, technology consultant, businessman, law student and film producer), Internet technologies reduced the barriers to participation and facilitated teamwork among activists.

"I think we just had one meeting before we came up with our paper, just that one face-to-face meeting, and after that everything was done over emails." (George, male, early 30s, technology consultant and opposition party member)

Besides providing activists with an efficient means to coordinate and organize online work, Internet technologies enable them to engage in activism work that would otherwise be very timeconsuming. During the 1997 Singapore General Election, the Internet made it possible for Madcow (then a university student) and several other activists to work as a team in gathering and disseminating information that was not published in the mainstream media through Soc Culture Singapore (a discussion bulletin board which has ceased operations). Other than facilitating cooperation among a group of people who have not met one another, the Internet also helped them to schedule and coordinate their reporting activities effectively and produce daily updates on political rallies on days leading up to the general election.

Such convenience and ease of participation significantly lowered barriers to participation for activist bloggers. Chong admitted candidly the ease of communication and information-sharing through emails made it more difficult to reject overtures for help and easier to agree to lending one's expertise and knowledge, especially when compared to times prior to the advent of Internet technologies. 
"For example, a typical thing I might be asked to help with would be to take a look at press release or brochures on ways to write things better for any groups that need advice. Without the Internet, if someone were to call me and say, "I have this one-page document which I would like you to go over," I would have to stand by a fax machine. If they don't trust the fax and you have to have a physical meeting, there would be a very high chance that you would say "No" because you are busy. Now the automatic response would be to say "Yes." They just email it to you and you can look at it at midnight after you have done everything else." (Chong, male, mid 40s, professor in journalism studies)

\section{Conclusion}

As presented earlier, social movement theories play an integral role in explaining why one participates in collective action. However, a problem with most social movement theories is their exclusive focus on either structural or individual factors, resulting in a lack of clarity pertaining to "the mediating process between them" (Langman, 2005, p.49). Furthermore, the majority of social movement studies have by and large, excluded the role of technology in helping collective action actors to overcome limitations and challenges embedded in their institutional structure. This study thus provides a timely response to the existing lacuna in collective action research. It combines approaches in political economy studies, micro-structural analysis and Internet studies to engender deeper insights into technology use for collective action. The practices and meanings behind technology use have to be understood in the light of institutional contexts which in turn shape micro-structural variables of participation.

In Singapore, myriad laws and measures implemented since the early days of Singapore's independence have discouraged civic engagement on the part of the citizens. Laws that prohibit "illegal" public assemblies and speech that oversteps the boundaries of what is deemed as acceptable discourse are two main impediments for civic engagement and political participation. By adopting an institutional and micro-structural approach, this study has shed light on how activist bloggers use Internet technologies such as blogs and social media to overcome limitations posed by a lack of collective incentives, structural proximity and structural availability.

Since independence, local politics have seen the domination of a one-party system in which the People's Action Party occupies an overwhelming number of parliamentary seats. A competent and uncorrupt governance based on consensus-driven policy-making, supported by traditional media which maintain social and racial cohesiveness, has been the raison d'être of local politics. Perceptions of the opposition's marginalization and traditional media being the mouthpiece of the ruling party led to the migration of anti-establishment voices to the cyberspace.

Internet technologies enable activists to communicate and work with like-minded activists in pushing for political and social change. Collective incentives are increased and they affirm activist bloggers' conviction pertaining to the importance of blogging about their activism work. Although a common reason provided by all political bloggers for blogging was to contribute to civic discourse, what unite activist bloggers are their common objects of opposition - the government and mainstream media.

In terms of building connections and networks, this study confirms that Internet technologies as well as social media, e.g., Facebook, bring people from diverse backgrounds together in cyberspace and cultivate a shared or collective goal, echoing proponents such as Ceren (2006) and Custard (2007). Qualitative data from the interviews explicated how activist bloggers leveraged digital platforms to forge connections with those sharing similar political ideologies and interests. This was especially so for offline-based activists who engaged in highly visible and sometimes controversial activist activities. Hence online networks help establish the foundation for the formation of alliances and friendships by connecting like-minded individuals who oppose political and media hegemony, and have the interest and determination to be agents of change. The World Wide Web became a meeting place for activists who were not aware of one another's interest or 
even existence. By exposing political bloggers who are predisposed to being active in politics and civic activities, Internet technologies build critical bridges among veteran and fledging activists.

Preliminary observations of the Singapore blogosphere, substantiated by interview data in this study, suggest that the blogosphere in Singapore is characterized by bloggers assuming the role of alternative media, critics who provide commentary and analyses of Singapore politics and government policies. This is in stark contrast to the U.S. context where studies have shown the blogosphere to be a largely partisan one, split between the liberals and conservatives (Adamic \& Glance, 2005; Hargittai, Gallo \& Kane, 2008). The differences in political culture, regulatory regime and media system have also led to bloggers assuming different roles in both countries. Although this study examines how technology is used to negotiate the institutional terrain in a semiauthoritarian regime, it nevertheless reflects a critical extension in a literature that is typically North American centric and calls for comparative analyses of how new media technologies interact with collective action in different regimes.

\section{References}

Adamic, L. A., \& Glance, N. (2005). The political blogosphere and the 2004 U.S. election: divided they blog. Proceedings from Conference on Knowledge Discovery in Data, proceedings of the 3rd international workshop on Link discover (pp.36-43), Chicago, Illinois, USA.

Ayers, M. D. (2003). Comparing collective identity in online and offline feminist activists. In M. McCaughey, \& M. D. Ayers (Eds.), Cyberactivism: Online activism in theory and practice (pp.145-164). New York, NY: Routledge.

Banerjee, I. (2002). The locals strike back? Gazette: The International Journal for Communications Studies, 64(6), 517-535.

Biddix, P. J., \& Park, H. W. (2008). Online networks of student protest: The case of the living wage campaign. New Media \& Society, 10(6), 871-891.

Bosch, T. (2010). Digital journalism and online public spheres in South Africa. Communicatio, 36(2), 265-275.

Buechler, S. M. (1993). Beyond resource mobilization? Emerging trends in social movement theory. Sociological Quarterly, 34(2), 217-235.

Buechler, S. M. (1995). New social movement theories. Sociological Quarterly, 36(3), 441-464.

Chew, C. (2009, August 15). Young crusaders. The Straits Times, pp. D1-9.

Chew, S-B. \& Chew, R. (1995), Immigration and foreign labour in Singapore. ASEAN Economic Bulletin, 12(2), 191-200.

Chew, P. \& Tan, E.S. (1993). Tribute. In J.L. Lam (Ed.), Voices and choices - The women's movement in Singapore (pp.146-147). Singapore: Singapore Council of Women's Organizations and Singapore Baha'i Women's Committee.

Christensen, H.S. (2011). Political activities on the Internet: Slacktivism or political participation by other means? First Monday, 16(2), Retrieved from http://firstmonday.org/htbin/cgiwrap/bin/ojs/index.php/fm/article/view/3336/2767.

Coston, J.M. (1998). A model and typology of government-NGO relationships. Nonprofit and Voluntary Sector Quarterly, 27, 358-382.

Della Porta, D. (1995). Social movements, political violence and the state. Cambridge: Cambridge University Press.

Della Porta, D., \& Diani, M. (2006). Social movements: An introduction (2nd edition) (pp.33-63, 89-113). Oxford: Blackwell Publishing.

Diani, M. (2000). Social movement networks virtual and real. Information, Communication \& Society, 3(3), 386-401.

Dixon, M., \& Roscigno, V. J. (2003). Status, networks, and social movement participation: The case of striking workers. American Journal of Sociology, 108(6), 1292-1327.

Flew, T. (2005). New media: An introduction (pp.xv-xxii). Melbourne, Victoria: Oxford University Press.

Fiore-Silfvast, B. (2009, October). User-generated warfare: network armies take on YouTube. Presented at AolR Conference "Internet Research 10.0: Internet-Critical", Milwaukee, Wisconsin, USA.

Flanagin, A. J., Stohl, C., \& Bimber, B. (2006). Modeling the structure of collective action. Communication Monographs, 73(1), 29-54.

Garrido, M. I., \& Halavais, A, (2003). Mapping networks of support for the Zapatista movement. In M. McCaughey, \& M. D. Ayers (Eds.), Cyberactivism: Online activism in theory and practice (pp.145-164). New York, NY: Routledge.

George, C. (2003). The Internet and the narrowing tailoring dilemma for "Asian" democracies. The Communication Review, $6,247-268$. 
Gil de Zuniga, H., Veenstra, A., Vraga, E., \& Shah, D. (2010). Digital democracy: Reimagining pathways to political participation. Journal of Information Technology \& Politics, 7, 36-51.

Gillis, E.K. (2005). Singapore civil society and British power. Singapore: Talisman.

Gould, R. V. (1991). Multiple networks and mobilization in the Paris commune, 1871. American Sociological Review, 56(6), 716-729.

Graber, D. A. (2001). Processing politics: Learning from television in the internet age. Chicago, Illinois: University Press of Chicago.

Hannigan, J. A. (1985). Alain Touraine, Manuel Castells and social movement theory: A critical appraisal. Sociological Quarterly, 26(4), 435-454.

Hargittai, E., Gallo, J. \& Kane, M. (2008). Cross-ideological discussions among Conservative and Liberal Bloggers. Public Choice, 1-2, 67-86.

Haythornthwaite, C. (2002). Strong, weak and latent ties and the impact of new media. The Information Society, 18(5), 385401.

Ho, K. C., Baber, Z., \& Khondker, H. (2002). 'Sites' of resistance: Alternative web sites and state-society relations. British Journal of Sociology, 53(1), 127-148.

Ibrahim, Y. (2009). Textual and symbolic resistance: Re-mediating politics through the blogosphere in Singapore. In A. Russell, \& N. Echchaibi (Eds.), International blogging (pp.173-198). New York, NY: Peter Lang Publishing.

Infocomm Development Authority of Singapore. (2010). Annual survey on infocomm usage in households and by individuals for 2010. Retrieved from http://www.ida.gov.sg/doc/Publications/Publications Level3/Survey2010/HH2010ES.pdf

International Telecommunication Union. (2011). The world in 2011, ICT facts and figures. Retrieved from October 1, 2012 http://www.itu.int/ITU-D/ict/facts/2011/material/ICTFactsFigures2011.pdf

Jenkins, C. J. (1983). Resource mobilization theory and the study of social movements. Annual Review of Sociology, 9, 527553.

Klandermans, B. (1984). Mobilization and participation: Social-psychological expansions of resource mobilization theory. American Sociological Review, 49(5), 583-600.

Klandermans, B. (1993). A theoretical framework for comparisons of social movement participation. Sociological Forum, 8(3), 383-402.

Klandermans, B. (1984). Mobilization and participation: Social-psychological expansions of resource mobilization theory. American Sociological Review, 49(5), 583-600.

Klandermans, B., \& Oegema, D. (1987). Potentials, networks, motivations, and barriers: Steps towards participation in social movements. American Sociological Review, 52(4), 519-531.

Koh, G. \& Ooi, G.L. (2004). Relationship between state and civil society in Singapore: Clarifying the concept, assessing the ground. In Lee H.G. (Ed.), Civil society in Southeast Asia (pp.167-197). Singapore: ISEAS Publications.

Kreimer, S. F. (2001). Technologies of protest: Insurgent social movements and the First Amendment in the era of the Internet. University of Pennsylvania Law Review, 150(1), 119-171.

Kvale, S. (1996). Interviews: An introduction to qualitative research interviewing. Thousand Oaks, CA: Sage Publishing.

Kuo, C. Y. (1995). The making of a new nation: Cultural construction and national identity. In B. H. Chua (Ed.), Communitarian ideology and democracy in Singapore (pp. 101-123). London: Routledge.

Langlois, G., Elmer, G., McKelvey, F., \& Devereaux, Z. (2009). Networked publics: The double articulation of code and politics on Facebook. Canadian Journal of Communication, 34, 415-434.

Langman, L. (2005). From virtual public spheres to global justice: A critical theory of internetworked social movements. Sociological Theory, 23(1), 42-74.

Locher, D.A. (2002). Collective behavior. (pp.231-247). Upper Saddle River, NJ: Prentice Hall.

McAdam, D. (1986). Recruitment to high-risk activism: The case of Freedom Summer. American Journal of Sociology, 92, 64-90.

McAdam, D., \& Paulsen, R. (1993). Specifying the relationship between social ties and activism. American Journal of Sociology, 99, 640-67.

McAdam, D., Tarrow, S., \& Tilly, C. (2001). Dynamics of contention. New York, NY: Cambridge University Press.

McCaughey, M., \& Ayers, M.D. (2003). Cyberactivism: Online activism in theory and practice. New York, NY: Routledge.

Olson, M. (1965). The logic of collective action: Publics goods and the theory of groups. Cambridge, MA: Harvard University Press.

Olson, M. (1968). The logic of collective action. New York, NY: Schocken. 
Passy, F., \& Giugni, M. (2000). Social networks and individual perceptions: Explaining differential participation in social movements. Sociological Forum, 16(1), 123-153.

Pfaff, S. (1996). Collective identity and informal groups in revolutionary mobilization: East Germany in 1989. Social Forces, 75(1), 91-117.

Rodan, G. (1998). The Internet and Political Control in Singapore. Political Science Quarterly, 113(1), 63-89.

Sessions, L. (2010, June). How offline gathering affects online communities? Presented at International Communication Association conference, Singapore.

Silcock, T.H. (1962). Singapore cross-roads. The Australian Quarterly, 34(2), 81-87.

Snow, D. A., Zurcher L. A. J., \& Ekland-Olson, S. (1980). Approach to differential recruitment. American Sociological Review, 45(5), 787-801.

Stein, L. (2007, May). National social movement organizations and the World Wide Web: A survey of web-based activities and attributes. Presented at International Communication Association conference, San Francisco, California, U.S.A.

Tan K.P. (2007). New politics for a renaissance city? In K.P. Tan (Ed.), Renaissance Singapore? (pp.17-36). Singapore: NUS Press.

Tan, W. (2008, August 9). Rise of online activists. The Straits Times, p. B11.

Tilly, C. (2004). Social movements, 1768-2004. Boulder, CO: Paradigm Publishers.

Van Laer, J., \& Van Aelst, P. (2010). Internet and social movement action repertoires. Information, Communication \& Society, 13(8), 1146-1171.

Vegh, S. (2003). Classifying forms of online activism: the case of cyberprotest against the World Bank. In M. McCaughey, \& M. D. Ayers (Eds.), Cyberactivism: Online activism in theory and practice (pp.71-95). New York, NY: Routledge.

Wasserman, S., \& Faust, K. (1994). Social network analysis: Methods and applications. New York, NY: Cambridge University Press.

Wellman, B., \& Gulia, M. (1999). Virtual communities as communities: Net surfers don't ride alone. In M. Smith \& P. Kollock (Eds.), Communities in cyberspace. London: Routledge.

Winner, L. (2003). The Internet and dreams of democratic renewal. In D.M. Anderson \& M. Cornfield (Eds.), The civic web: online politics and democratic values (pp.167-184). Lanham, MD: Rowman \& Littlefield.

Zhao, D. (1998). Ecologies of social movements: Student mobilization during the 1989 prodemocracy movement in Beijing. American Journal of Sociology, 103(6), 1493-1529.

\section{About the Author}

Carol Soon

Dr. Carol Soon is Research Fellow at the Institute of Policy Studies, Lee Kuan Yew School of Public Policy. She completed her Ph.D. in the National University of Singapore and her research interests include digital engagement, and how individuals and organizations leverage new media to engender political and social change. Her work has been published in peerreviewed journals and her recent paper on political bloggers and collective identity has been accepted by the Journal of Computer-Mediated Communication for publication. In 2012, Dr. Soon was Visiting Research Fellow at the Asia Research Centre, Murdoch University, with support from the Australian Endeavour Award. 